\title{
Experimental development of apparatus to measure piston assembly friction in an eco-mileage vehicle engine
}

\begin{abstract}
Apparatus was developed to measure piston assembly friction with a floating cylinder liner against crank angle, using components of an eco-mileage vehicle engine as much as possible. This apparatus was then used to investigate the effect of different sets of piston rings on piston assembly friction in an eco-mileage vehicle engine. Results indicated that, compared to the piston with all three rings (a top ring, a second ring and an oil ring), the piston with two rings (a top ring and an oil ring) reduced piston assembly friction at all engine temperatures and engine speeds. Another configuration of two rings, with the top ring and the second ring, but without the oil ring, reduced friction at a lower engine temperature and speed, but was almost the same as the three-ring set at a higher engine temperature and speed. Finally, a one-ring set, with only the top ring, further reduced friction, except at a higher temperature and speed, where friction was greater than the two-ring set without the second ring.
\end{abstract}

Key words: eco-mileage vehicle engine, floating cylinder liner, piston assembly friction, piston ring, piston skirt

\section{Introduction}

Eco-mileage vehicles (Fig. 1) compete by running a fixed number of laps around a track within a given time. Judges calculate fuel efficiency $(\mathrm{km} / \mathrm{L})$, and name a winner. Reducing not only vehicle running resistance but also engine friction, are effective means for improving fuel efficiency. The piston assembly friction (the friction between the piston, the piston rings, and the cylinder liner) makes a significant contribution to engine friction $[2,8]$. So it is important to reduce the piston assembly friction. Reports have investigated the effects on the piston assembly friction in automobile engines from piston ring tension $[3,4,9]$, surface treatment of the ring $[13,16]$, piston skirt profile $[6,7]$, and surface treatment of the piston skirt $[10$, 12]. In practice, in order to reduce piston assembly friction in an eco-mileage vehicle engine, the typical set of three rings (a top ring, a second ring, and an oil ring) is often replaced with a two-ring set, by removing either the second ring or the oil ring from the piston, or even by removing both the second ring and the oil ring, leaving a one-ring set (with just the top ring). However, no reports have investigated how much piston assembly friction is reduced by such removal of rings from the piston. As candidates for the measurements of such piston assembly friction against crank angle during the engine operation, there are the floating cylinder liner method $[1,3,7,13,15$, 16], the three-component force sensor method [4-6, 9-11], and the instantaneous indicated mean effective pressure (IMEP) method [14]. Among these measurement methods, the floating liner method is most commonly used. But the floating liner method generally requires significant engine modifications, such as producing a special cylinder liner. This study developed a friction measurement apparatus with a floating cylinder liner, by using components of an eco-mileage vehicle engine as much as possible. Using this measurement apparatus, the effect of each ring on piston assembly friction was examined, while varying the temperature of the engine and the lubricant, as well as the engine speed.

\section{Experimental apparatus and method}

Figures 2 and 3 show the measurement apparatus of the piston assembly friction with the floating liner. This measurement apparatus used a commercially-available, fourstroke, air-cooled, horizontal, single-cylinder, gasoline engine, displacing $49 \mathrm{~mL}$, with a bore diameter of $39 \mathrm{~mm}$ and a stroke of $41.4 \mathrm{~mm}$. The crankcase of this engine was cut, and a cover was attached to the cut of the crankcase. The engine was turned from horizontal to vertical, to match the orientation in an eco-mileage vehicle. For the floating liner, the outer periphery of the air-cooled cylinder (aluminum finned cylinder casting cast-iron liner) was turned, and the grooves for the joint plates were machined on its outer periphery at the thrust and the anti-thrust side, and then the grooves for the clamping bolts were machined at the thrust, the anti-thrust, the front, and the rear sides. As shown in Fig. 3 , joint plates were installed in the grooves on the outer periphery of the floating liner, and then the plates, as well as load washers of piezo type, were mounted in the cylinder block, at both the thrust and the anti-thrust sides. Because the cylinder liner is completely supported by the joint plates, any vertical force in the cylinder liner is applied to the joint plates, and thence to the load washers. Thus it is possible to measure the friction in the sliding directions of the piston. In addition, to suppress lateral displacement due to piston thrust force, clamping bolts were mounted to the cylinder block at the thrust, the anti-thrust, the front, and the rear sides.

Heaters were installed in the cylinder block at the thrust, the anti-thrust, and the rear sides, and thermocouples were installed into the clamping bolts at the front and the rear sides so that the bore surface temperature of the liner could be adjusted and measured.

The measurement apparatus was changed from a wet sump in the commercially-available engine to a dry sump. The heater and the thermocouple were inserted into the oil tank outside the engine. The lubricant was Honda genuine Ultra Green with a lower viscosity for low-fuel consumption engines. The lubricant at a fixed temperature was pumped from the oil tank to the pipe in the upside of the 
crankcase, and then applied from its pipe to the crankshaft at a flow rate of $600 \mathrm{~mL} / \mathrm{min}$.

Figure 4 shows the experimental piston, which is standard part of the commercially-available engine. This piston has three grooves in the skirt. As shown in Fig. 5, the roughness of the skirt sliding surface (other than the grooves) was $\mathrm{Ra} 2.21 \mu \mathrm{m}$ on the thrust side and $\mathrm{Ra} 2.51 \mu \mathrm{m}$ on the anti-thrust side (after the experiment).

Table 1 shows the experimental rings, which are also standard parts of the commercially-available engine. Table 2 shows the tested combinations of ring sets. The effects of the absence of either the second ring or the oil ring (in the two-ring sets), and of the absence of both the second ring and the oil ring (in the one-ring set) on piston assembly friction were examined, in comparison with the three-ring set (comprising the top ring, the second ring and oil ring) in the commercially-available engine.

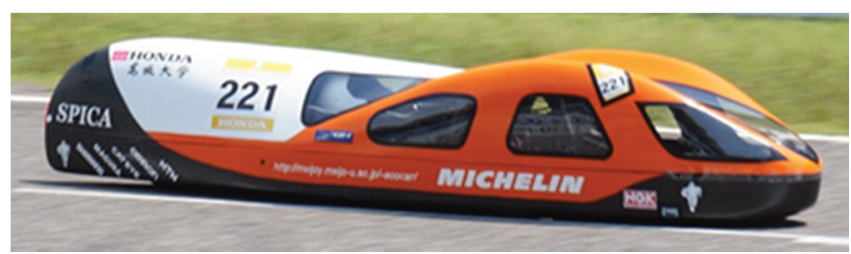

Fig. 1. Eco-mileage vehicle

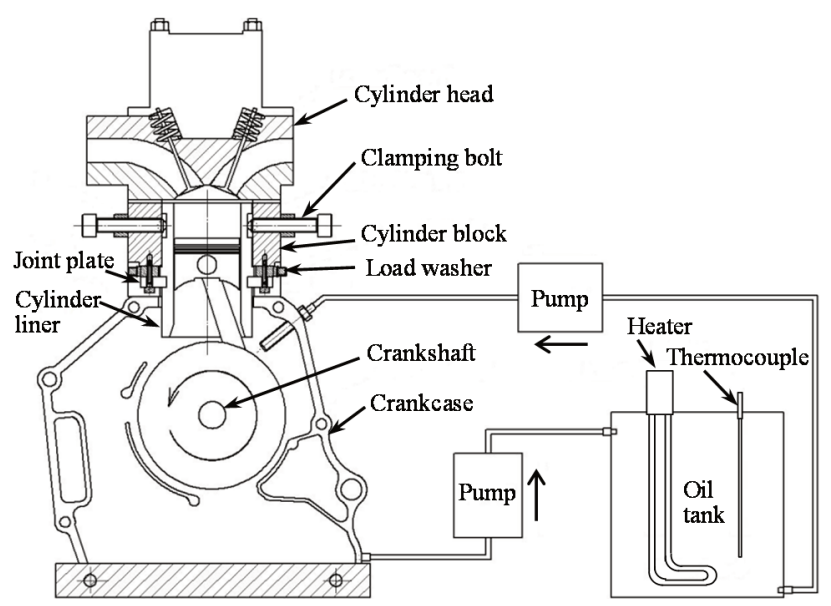

Fig. 2. Measurement apparatus of piston assembly friction

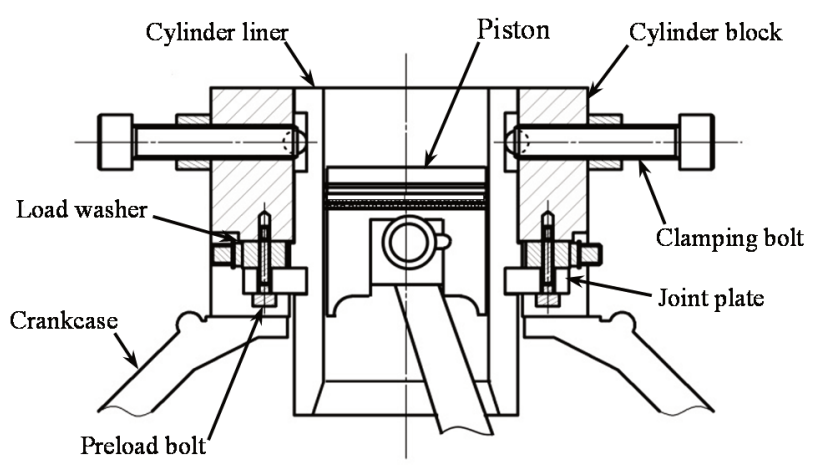

Fig. 3. Measurement unit of piston assembly friction with floating liner

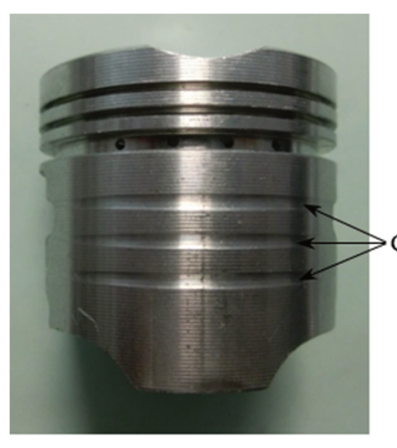

(i) Thrust side

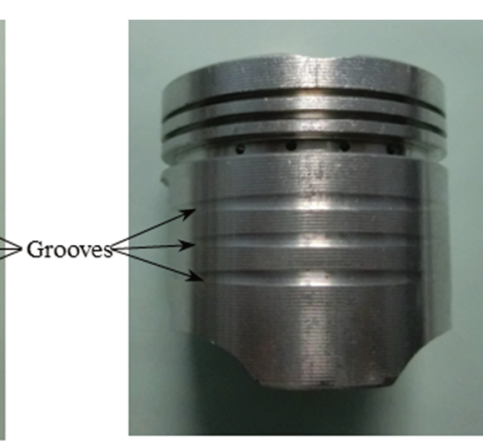

(ii) Anti-thrust side
Fig. 4. Experimental piston

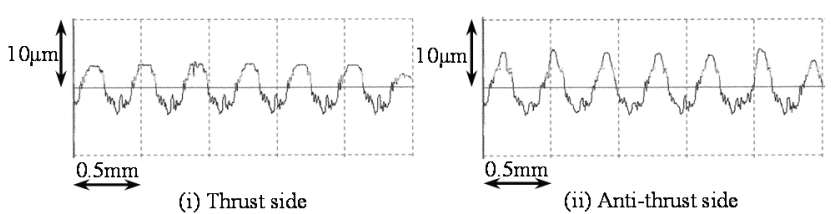

Fig. 5. Roughness of piston skirt sliding surface other than grooves (after experiment)

Table 1. Experimental piston rings

\begin{tabular}{|l|l|l|}
\hline \multicolumn{1}{|c|}{ Top ring } & \multicolumn{1}{|c|}{ Second ring } & Oil ring \\
\hline & & \\
\hline
\end{tabular}

Table 2. Combinations of piston ring sets

\begin{tabular}{|l|c|c|c|}
\hline & Top ring & Second ring & Oil ring \\
\hline Three-ring set & With & With & With \\
\hline $\begin{array}{l}\text { Two-ring set without second } \\
\text { ring }\end{array}$ & With & Without & With \\
\hline Two-ring set without oil ring & With & With & Without \\
\hline One-ring set & With & Without & Without \\
\hline
\end{tabular}

The roughness of the sliding surface on the liner bore was $\mathrm{Rz}_{\mathrm{IIS}} 1.34 \mu \mathrm{m}(\mathrm{Ra} 0.20 \mu \mathrm{m})$ on the thrust side and $\mathrm{Rz}_{\mathrm{IIS}}$ $1.22 \mu \mathrm{m}(\operatorname{Ra} 0.22 \mu \mathrm{m})$ on the anti-thrust side, after the experiment.

In the experiment, the cylinder head was attached, but the intake and the exhaust valves were not activated, and the piston assembly friction was measured by motoring operation. A preliminary experiment confirmed that the cylinder head (in which the valves were not activated) has a minimum effect on the piston assembly friction, because of the small displacement in this engine. However, in order to make it easy to adjust the temperature on the liner bore, the cylinder head was attached, and an insulation cover was put on the cylinder head and the cylinder block. Before the measurement of the piston assembly fiction, the engine was fully run in. Experiments were performed at temperatures of the liner bore and the lubricant of $40^{\circ} \mathrm{C}$ to $80^{\circ} \mathrm{C}$ and at engine speeds of $800 \mathrm{rpm}$ to $1600 \mathrm{rpm}$. 


\section{Results and discussion}

Figure 6 shows the effect of temperature of the liner bore and the lubricant on piston assembly friction with a three-ring set at an engine speed of 1000 rpm. In Fig. 6, crank angles of $0^{\circ}$ and $360^{\circ}$ represent engine top dead center (TDC), and $180^{\circ}$ bottom dead center (BDC). Since this time the intake and the exhaust valves were not activated, only the two strokes of the piston (downward stroke and upward stroke) were indicated. During the piston downward stroke, a downward force is applied to the liner, and during the piston upward stroke, an upward force is applied to the liner. These forces (frictions) are indicated as negative force and positive force, respectively

As shown in Fig. 6, as the temperature of the liner bore and the lubricant was raised, the friction around TDC and BDC also increased, but the friction in the middle of the stroke decreased. Figure 7 shows the friction mean effective pressure (FMEP) with the three-ring set. Here the FMEP was obtained by integrating the absolute value of friction at crank angles of $0^{\circ}$ to $360^{\circ}$ and dividing by the stroke volume. In Fig. 7, the FMEP increased with increased engine speed, but the FMEP decreased with increased temperature.

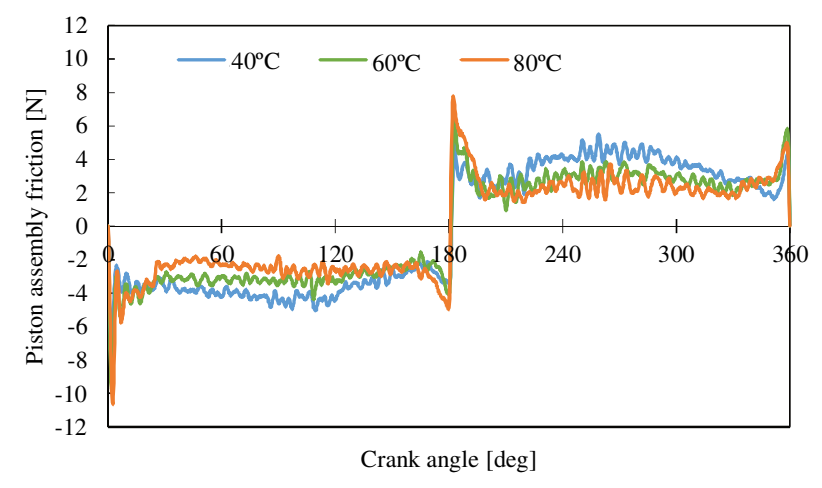

Fig. 6. Effect of temperature on piston assembly friction with three-ring set at $1000 \mathrm{rpm}$

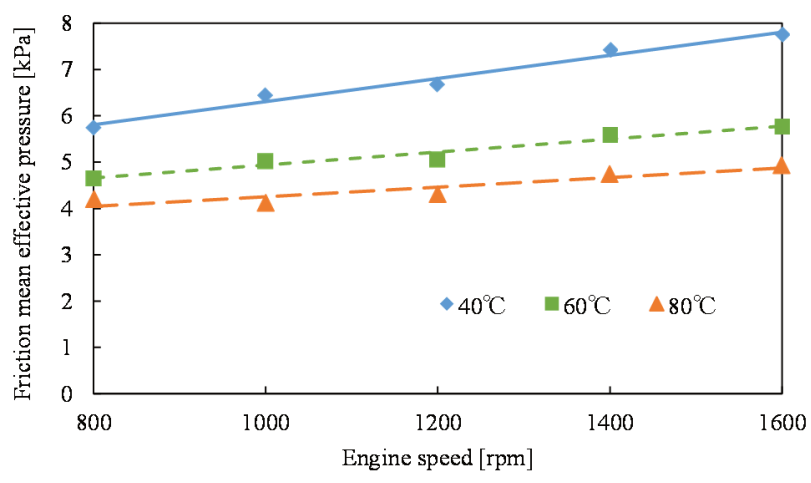

Fig. 7. Friction mean effective pressure (FMEP) with three-ring set

Figure 8 shows the FMEP with a two-ring set without the second ring (with the top and the oil rings). At each temperature and engine speed, the FMEP with this two-ring set without the second ring was lower than that with the three-ring set. As shown in Fig. 9, the friction with the tworing set was lower around TDC and BDC and in the middle of the stroke, compared with the three-ring set. It appears that friction is decreased when removing the second ring, thus eliminating the contribution of the second ring tension.

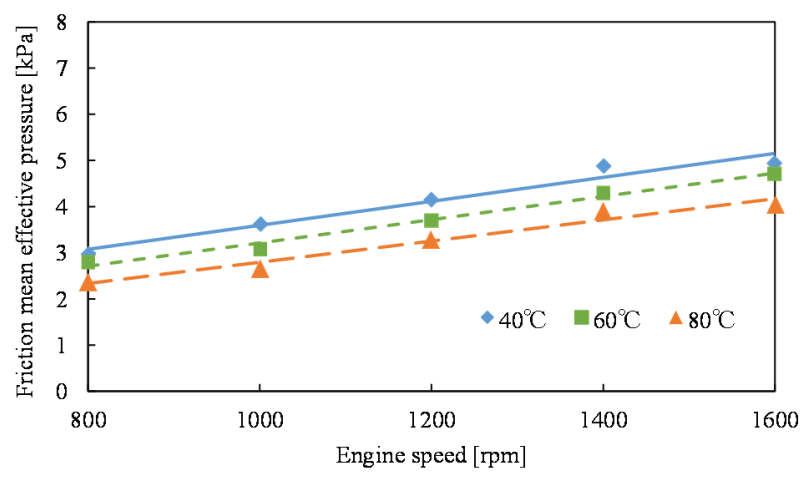

Fig. 8. FMEP with two-ring set without second ring

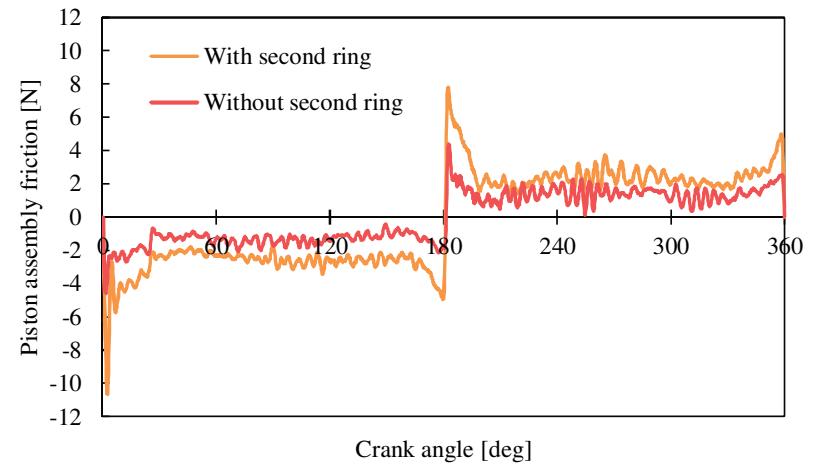

Fig. 9. Effect of absence of second ring on piston assembly friction $\left(80^{\circ} \mathrm{C}\right.$, $1000 \mathrm{rpm})$

Figure 10 shows the FMEP with a two-ring set without the oil ring (with the top and the second rings). At $40^{\circ} \mathrm{C}$, and at $60^{\circ} \mathrm{C}$ at $800 \mathrm{rpm}$ and $1000 \mathrm{rpm}$, the FMEP with the two-ring set without the oil ring was lower than that with the three-ring set. However at $60^{\circ} \mathrm{C}$ at more than $1000 \mathrm{rpm}$, and at $80^{\circ} \mathrm{C}$, the FMEP with the two-ring set without the oil ring was almost the same as that with the three-ring set. At $40^{\circ} \mathrm{C}$, and at $60^{\circ} \mathrm{C}$ at $800 \mathrm{rpm}$ and $1000 \mathrm{rpm}$, the friction with the two-ring set without the oil ring was lower in the middle of stroke than that with the three-ring set (Fig. 11). At $60^{\circ} \mathrm{C}$ at more than $1000 \mathrm{rpm}$, and at $80^{\circ} \mathrm{C}$, the friction with the two-ring set without the oil ring was almost the same as that with the three-ring set in the middle of the stroke (Fig. 12). At each temperature and engine speed, the friction with the two-ring set without the oil ring was almost the same as that with the three-ring set around TDC and BDC. It is thought that, by removing the oil ring with the highest tension, a narrow running face of the second ring makes strong contact with the liner around TDC and BDC. Then the reduction of the friction by removing the oil ring is offset by the increase of the friction of the second ring there. At a higher engine speed and a lower load, among the piston assembly friction, the ratio of the piston friction to the ring friction increases [11]. Furthermore, it seems that, by removing the oil ring, the piston skirt makes strong contact with the liner at a higher temperature and a higher engine speed. It is considered that, in the middle of the stroke, the reduction of the friction by removing the oil 
ring is offset by the increase of the piston friction. So the friction did not decrease at $60^{\circ} \mathrm{C}$ at more than $1000 \mathrm{rpm}$, and at $80^{\circ} \mathrm{C}$.

Figure 13 shows the FMEP with a one-ring set of only the top ring, without the second and the oil rings. At each temperature and engine speed, the friction with this onering set was lower around TDC and BDC and in the middle of the stroke, than that with the three-ring set. So the FMEP with the one-ring set was also lower than that with the three-ring set. However in this one-ring set (with only the top ring), at more than $800 \mathrm{rpm}$, the FMEP at $80^{\circ} \mathrm{C}$ was higher than that at $60^{\circ} \mathrm{C}$.

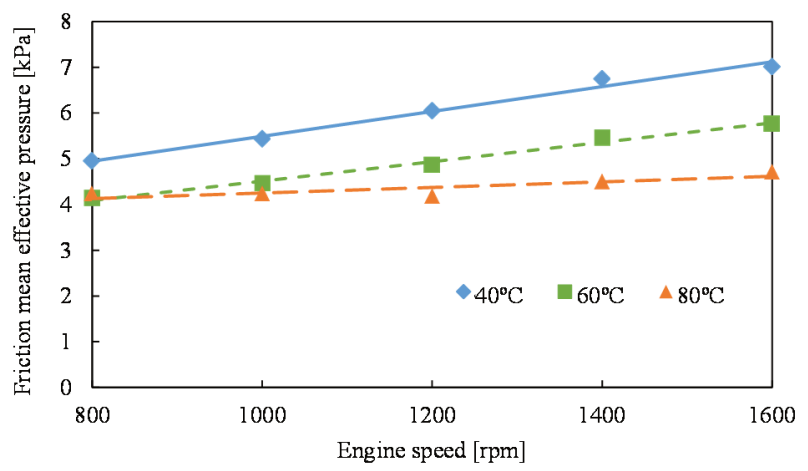

Fig. 10. FMEP with two-ring set without oil ring

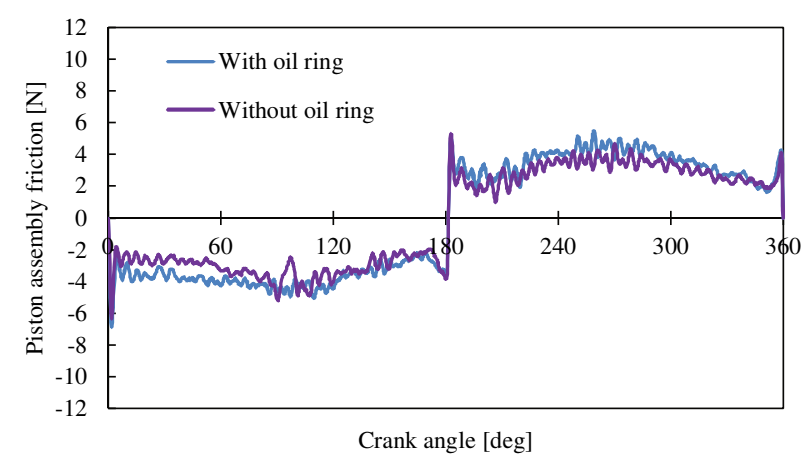

Fig. 11. Effect of absence of oil ring on piston assembly friction at $40^{\circ} \mathrm{C}$ and $1000 \mathrm{rpm}$

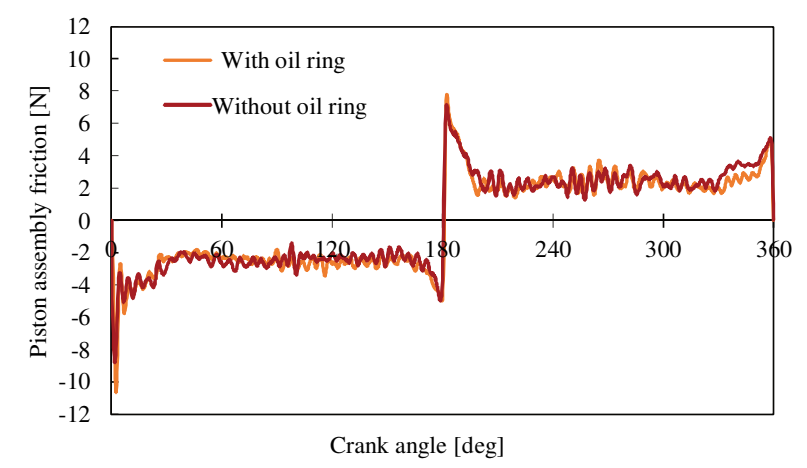

Fig. 12. Effect of absence of oil ring on piston assembly friction at $80^{\circ} \mathrm{C}$ and $1000 \mathrm{rpm}$

At more than $800 \mathrm{rpm}$, the friction with the one-ring set at $80^{\circ} \mathrm{C}$ increased around TDC and BDC beyond that at $60^{\circ} \mathrm{C}$ (Fig. 14). At $80^{\circ} \mathrm{C}$, the oil viscosity is reduced, so the piston skirt with the one-ring set makes strong contact with the liner around TDC and BDC where the piston speed is lower. It seems that a boundary lubrication condition becomes dominant between the piston skirt and the liner, and then the friction increases there.

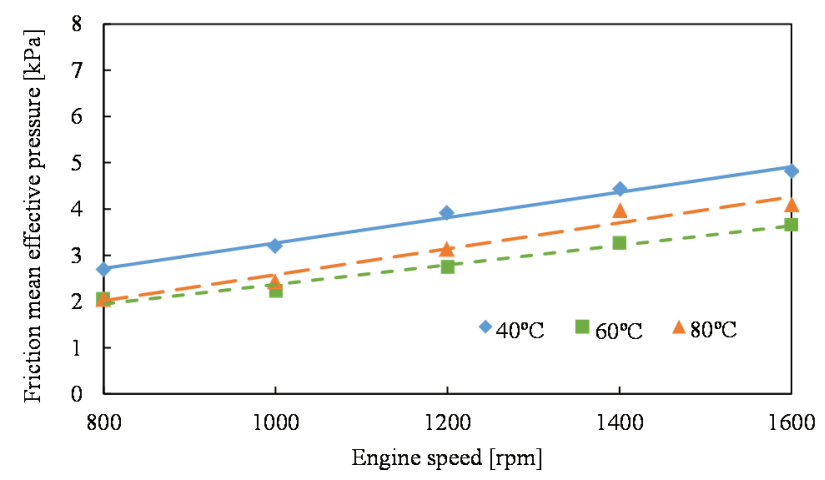

Fig. 13. FMEP with one-ring set without second and oil rings

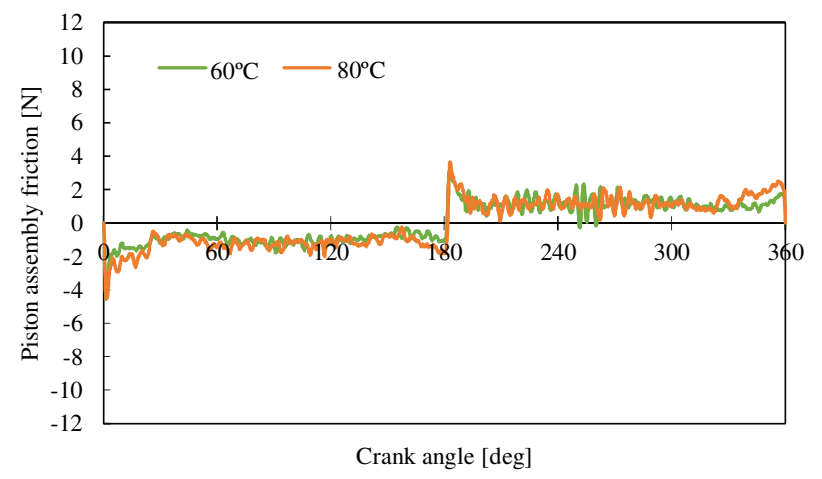

Fig. 14. Effect of temperature on piston assembly friction with one-ring set at $1000 \mathrm{rpm}$

At $40^{\circ} \mathrm{C}, 60^{\circ} \mathrm{C}$, and $80^{\circ} \mathrm{C}$ at between $800 \mathrm{rpm}$ and 1200 rpm, the one-ring set (of only the top ring) minimized the FMEP. The FMEP was reduced by $27 \%$ to $56 \%$ for the one-ring set compared to the three-ring set. At $80^{\circ} \mathrm{C}$ at more than $1200 \mathrm{rpm}$, the two-ring set (with the top and the oil rings) minimized the FMEP. The FMEP was reduced by $18 \%$ for this two-ring set (with the top and the oil rings) compared to the three- ring set.

\section{Conclusions}

Utilizing a friction measurement apparatus with a floating cylinder liner, the effect of each ring on piston assembly friction was investigated. Results indicate that, at $40^{\circ} \mathrm{C}$, $60^{\circ} \mathrm{C}$, and $80^{\circ} \mathrm{C}$ at $1200 \mathrm{rpm}$ or less, the friction is minimized with the one-ring set (of only the top ring), and at $80^{\circ} \mathrm{C}$ at $1400 \mathrm{rpm}$ or more, the friction is minimized with the two-ring set (with the top and the oil rings).

Future work will investigate the piston assembly friction under firing operation.

\section{Acknowledgements}

I would like to thank undergraduate school students $M r$. Haruhiko Niwa, Mr. Tomoaki Hayashi, Mr. Kanpei Kobayashi, and Mr. Ryota Ito, of Meijo University, at that time, for fruitful cooperation during this experimental work. 


\section{Nomenclature}

BDC bottom dead center

FMEP friction mean effective pressure

IMEP indicated mean effective pressure
$\mathrm{Ra} \quad$ calculated average roughness

$\mathrm{RZ}_{\mathrm{JIS}}$ 10-point average roughness

TDC top dead center

\section{Bibliography}

[1] FURUHAMA, S., TAKIGUCHI, M. Measurement of piston frictional force in actual operating diesel engine. SAE Technical Paper 790855. 1979. DOI:10.4271/790855.

[2] HOSHI, M. Introduction to automotive lubrication. Sankaido Publishing. 1979, 51-60 (in Japanese).

[3] IIJIMA, N., AOKI, S., IMAMURA, J., TAKIGUCHI, M. An experimental study on effect of lower tension piston rings on piston friction and lubricating oil consumption. Transactions of the Society of Automotive Engineers of Japan. 2009, 40(6), 1477-1482. DOI:10.11351/jsaeronbun. 40.1477 (in Japanese).

[4] INOUE, T., MURAKAMI, M., MASUDA, Y., KONOMI, T. A study of friction reduction on piston rings. Transactions of the Society of Automotive Engineers of Japan. 1996, 27(2), 46-50 (in Japanese).

[5] ITOH, Y., KONOMI, T., IWASHITA, Y. Analysis of piston friction on firing conditions by 3-component force sensor method. Transactions of the Society of Automotive Engineers of Japan. 1988, 37, 163-169 (in Japanese).

[6] KONOMI, T., NOHIRA, H., MURAKAMI, M., SANDA, S. Effects of piston skirt profile on friction loss and oil film behaviour. Proceedings of IMechE C465/011/93. 1993. 147154.

[7] MADDEN, D., KIM, K., TAKIGUCHI, M. Part 1: Piston friction and noise study of three different piston architectures for an automotive gasoline engine. SAE Technical Paper 2006-01-0427. 2006. DOI:10.4271/2006-01-0427.

[8] MATSUMOTO, K. Friction reduction in an internal combustion engine, Journal of the Japan Society of Mechanical Engineers. 1976, 79(694), 870-876. DOI:10.1299/jsmemag. 79.694_870 (in Japanese).

Prof. Kohei Nakashima, DEng. - Department of Vehicle and Mechanical Engineering, Meijo University, Japan.

e-mail:nakasima@meijo-u.ac.jp
[9] MURAKAMI, M., ITOH, Y., KONOMI, T., NOHIRA, H. Analysis of piston frictional force in engine firing condition -Effects of piston ring specifications on friction-. Transactions of the Society of Automotive Engineers of Japan. 1992, 23(4), 86-91 (in Japanese).

[10] MURAKAMI, M., KONOMI, T., NOHIRA, H. et al. Analysis of piston frictional force under engine firing condition -Effects of surface characteristics of piston skirt on friction-. Transactions of the Society of Automotive Engineers of Japan. 1991, 22(4), 70-73 (in Japanese).

[11] NAKANISHI, K., OKADA, Y., SERA, K. et al. New approach for piston assembly friction analysis based on empirical data, Transactions of the Society of Automotive Engineers of Japan. 2010, 41(2), 301-305. DOI:10.11351/jsaeronbun. 41.301 (in Japanese).

[12] OGIHARA, H. Modification of piston sliding surface for internal combustion engine by fine particle peeing of solid lubricant, Tribologist. 2002, 47(12), 895-900 (in Japanese).

[13] OKAMOTO, M., IWASHITA, T. Piston rings for automotive engine. Engine Technology. 2002, 4(3), 98-103 (in Japanese).

[14] URAS, H., PATTERSON, D. Measurement of piston and ring assembly friction instantaneous IMEP method. SAE Technical Paper 830416. 1983. DOI:10.4271/830416.

[15] WAKURI, Y., SOEJIMA, M., KITAHARA, T. et al. Characteristics of piston ring friction: Influences of lubricating oil properties. JSME International Journal Ser. C. 1995, 38(3), 593-600. DOI:10.1299/jsmec1993.38.593.

[16] YOSHIDA, H., KUSAMA, K., SAGAWA, J. Effects of surface treatments on piston ring friction force and wear. SAE Technical Paper 900589.1990. DOI:10.4271/900589.

Yosuke Uchiyama, BEng. - Department of Vehicle and Mechanical Engineering, Meijo University Graduate School, Japan.

e-mail:150446017@ccalumni.meijo-u.ac.jp
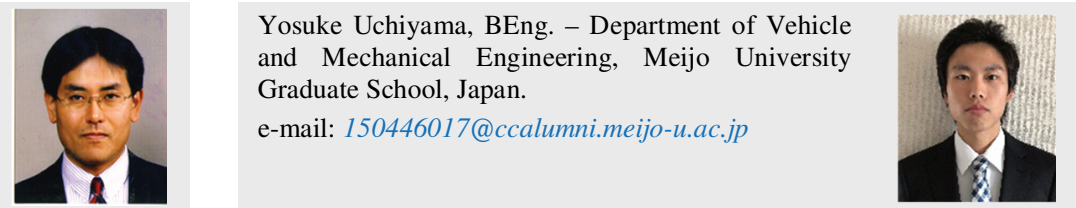